\title{
Calcium pyrophosphate powder derived from avian eggshell waste
}

\section{(Pó de pirofosfato de cálcio derivado de resíduo de casca de ovo galináceo)}

\author{
T. H.A. Corrêa, J. N. F. Holanda* \\ Grupo de Materiais Cerâmicos, LAMAV-CCT, Universidade Estadual do Norte Fluminense Darcy Ribeiro, \\ Av. Alberto Lamego, 2000, Campos dos Goytacazes, RJ, Brazil 28013-602 \\ tarciliafarmac@hotmail.com,*holanda@uenf.br
}

\begin{abstract}
Calcium pyrophosphate (CPP) was prepared by a simple precipitation method using avian eggshell waste as a low-cost alternative calcium precursor source. The synthesized CPP powder was characterized by X-ray diffraction (XRD), scanning electron microscopy (SEM/EDS), thermogravimetric analysis (TGA), and Fourier transform infrared spectroscopy (FTIR). The results indicate that pure $\beta$-CPP nanocrystallites $(\mathrm{Ca} / \mathrm{P}=1.067)$ were successfully synthesized from avian eggshell waste. The correlation among XRD, SEM/ EDS, TGA, and FTIR data is well established. The $\beta$-CPP particle exhibited spherical morphology with average crystallite size of $62.3 \mathrm{~nm}$, and can be an important bioceramic for medical applications.
\end{abstract}

Keywords: bioceramic, calcium pyrophosphate, eggshell waste, nanocrystallites.

\section{Resumo}

Pirofosfato de cálcio (CPP) foi preparado por um método de precipitação simples usando resíduo de casca de ovo galináceo como uma fonte precursora de cálcio de baixo custo. O pó de CPP sintetizado foi caracterizado em termos de difração de raios $X(D R X)$, microscopia eletrônica de varredura (MEV/EDS), análise termogravimétrica (ATG) e espectroscopia no infravermelho por transformada de Fourier (FTIR). Os resultados indicaram que nanocristalitos de $\beta$-CPP $(C a / P=1,067)$ foram sintetizados com sucesso a partir de resíduo de casca de ovo galináceo. A correlação entre resultados de DRX, MEV/EDS, ATG e FTIR é bem estabelecida. A partícula de $\beta$-CPP exibiu morfologia esférica com tamanho médio de cristalito de 62,3 nm, que pode ser uma importante biocerâmica para aplicações médicas.

Palavras-chave: biocerâmica, pirofosfato de cálcio, resíduo de casca de ovo, nanocristalitos.

\section{INTRODUCTION}

Hydroxyapatite (HAp) is an important calcium phosphate bioceramic material used in different medical and dental applications. It has a very similar chemical structure to that of bone and teeth tissues combined with good bioactive and osteoconductive properties [1,2]. In particular, HAp has been widely used as a substitute material for bone graft. Despite its importance, pure HAp has limited clinical use due to its low in vivo resorption rate [3]. This fact has attracted increasing interest in others calcium phosphate-based materials.

Calcium pyrophosphate $\left(\mathrm{Ca}_{2} \mathrm{P}_{2} \mathrm{O}_{7}, \mathrm{CPP}\right)$, one of the forms of calcium phosphate, also presents high potential to be used as a bone graft material [4]. The synthesis of pure CPP is considered to be a complex task due to its existence in three polymorphic forms ( $\beta$-CPP, $\alpha-\mathrm{CPP}$, and $\gamma$-CPP). However, the $\beta$-CPP phase is that of highest interest for use as bone graft material. Several methods and calcium sources have been employed to synthesize CPP powder [3, 5-7]. Nevertheless, the high purity calcium sources used in the synthesizing calcium phosphate-based materials are very costly. This has encouraged the use of alternative calcium sources, including the eggshell waste [8-13]. However, the synthesis of pure $\beta$-CPP nanopowder derived from avian eggshell waste has not yet been investigated.

Eggshell is a biowaste material composed mainly of calcium carbonate $\left(\mathrm{CaCO}_{3}\right)$. Everyday huge volumes of eggshell are generated worldwide, resulting in a serious problem of environmental pollution. Hence, its application in the bioceramic field could be one the best management practices for eggshell waste as a low-cost renewable raw material resource. In this work, a simple precipitation method to convert avian eggshell waste in $\beta$-CPP powder to be used as bone graft material was employed. The development of $\beta$-CPP powder with nanometric crystallites from a low cost renewable Ca-precursor source is of high scientific, medical, environmental, and economical interest.

\section{EXPERIMENTAL PROCEDURE}

The eggshell waste sample was supplied by a food company located in Campos dos Goytacazes-RJ, Brazil. The sample was washed with distilled water to remove the inner membrane layer. Then, it was dried at $110{ }^{\circ} \mathrm{C}$ for 24 $\mathrm{h}$, crushed into powder, and sieved through a 150 mesh (106 $\mu \mathrm{m}$ ASTM) sieve. X-ray diffraction analysis indicated that the eggshell waste powder is composed of pure $\mathrm{CaCO}_{3}$ (calcite). Chemically, the clean eggshell waste powder is 
essentially composed of calcium oxide $(\mathrm{CaO})$. The chemical reagents used were $\mathrm{HNO}_{3}$ (Vetec, 65\%) and $\mathrm{Na}_{2} \mathrm{HPO}_{4}$ (Sigma-Aldrich, 98\%).

The $\beta$-CPP powder was prepared from eggshell waste by using a wet precipitation method [14]. Briefly, the clean eggshell waste (pure $\mathrm{CaCO}_{3}$ ) was completely dissolved in $\mathrm{HNO}_{3}(1 \mathrm{M})$ with constant stirring for $2 \mathrm{~h}$, resulting in a $\mathrm{Ca}\left(\mathrm{NO}_{3}\right)_{2}(1 \mathrm{M})$ solution. The $\mathrm{Na}_{2} \mathrm{HPO}_{4}$ was slowly added to the $\mathrm{Ca}\left(\mathrm{NO}_{3}\right)_{2}$ solution, and the solution mixture was vigorously stirred for $2 \mathrm{~h}$ at $50{ }^{\circ} \mathrm{C}$. The resulting precipitate was vacuum filtered, washed with distilled water, and dried at $100{ }^{\circ} \mathrm{C}$ for $2 \mathrm{~h}$. Finally, the precipitate (powder) was calcined in air at $900{ }^{\circ} \mathrm{C}$ for $2 \mathrm{~h}$ by using a heating rate of $5{ }^{\circ} \mathrm{C} / \mathrm{min}$.

$\mathrm{X}$-ray diffraction (XRD) analysis of the as-prepared powder was performed with a conventional diffractometer (Ultima IV, Rigaku) using $\mathrm{Cu}-\mathrm{K} \alpha$ radiation, and $0.02 \%$ step and $5 \mathrm{~s}$ acquisition time. The average crystallite size (D) was determined by using the Scherrer equation according to $\mathrm{D}=$ $0.9 \lambda / \mathrm{B} \cdot \cos \theta$, where $\lambda$ is the wavelength of $\mathrm{Cu}-\mathrm{K} \alpha$ radiation $(\lambda=1.5406 \AA)$, B is the full width of the half maximum of the CPP line, and $\theta$ is the diffraction angle. The morphology of the powder particles was determined using a scanning electron microscopy (SEM, SSX-550, Shimadzu) attached with an energy dispersive X-ray spectrometer (EDS). Thermogravimetric analysis (TGA) was done with a TA Instrument SDT-2960, by using a heating rate of $10{ }^{\circ} \mathrm{C} / \mathrm{min}$ under air atmosphere. The Fourier transform infrared spectroscopy (FTIR) was carried out with a Spectrum 400 FTIR spectrophotometer (PerkimElmer) in the range from 400 to $4000 \mathrm{~cm}^{-1}$.

\section{RESULTS AND DISCUSSION}

Fig. 1 shows the XRD pattern of the as-synthesized CPP powder. All diffraction peaks were indexed to the tetragonal structured $\beta$-CPP (ICSD-PDF 01-071-2123) with unit cell parameters $\mathrm{a}=\mathrm{b}=6.6840 \AA, \mathrm{c}=24.1440 \AA$, and $\mathrm{P} 4$, space group. The highest intensity is observed at $29.7^{\circ} 2 \theta$ angle and d-spacing of $3.018 \AA$, corresponding to the (008) plane. These results indicate that the $\beta$-CPP powder synthesized via the wet precipitation method using avian eggshell waste was pure. The average crystallite size of the $\beta$-CPP powder determined by the Scherer's equation was found to be 62.3 $\mathrm{nm}$. The nanostructured nature of the synthesized powder has additional relevance, since $\beta$-CPP has a potential application as a bone graft material. Furthermore, this is the first report on pure $\beta$-CPP powder with nanometric crystallites obtained using avian eggshell waste as the calcium precursor source. Fig. 2 shows the SEM electron-micrograph of the $\beta$-CPP powder particles. As can be seen, the as-synthesized $\beta$-CPP particles show spherical morphology. In addition, $\beta$-CPP particles within the nanometric range is evident. Note also that the powder with nanometric crystallites is highly agglomerated. This agglomeration was caused by the calcination at $900{ }^{\circ} \mathrm{C}$ that pre-sintered the particles. EDS analysis of the $\beta$-CPP powder shown in Fig. 3 revealed the presence of $\mathrm{Ca}, \mathrm{P}$, and $\mathrm{O}$. This is consistent with XRD analysis (Fig. 1). The $\mathrm{Ca} / \mathrm{P}$ ratio was determined via SEMEDS analysis to be 1.067 , which is close to the theoretical value of $\beta$-calcium pyrophosphate $(\mathrm{Ca} / \mathrm{P}=1.000)$.

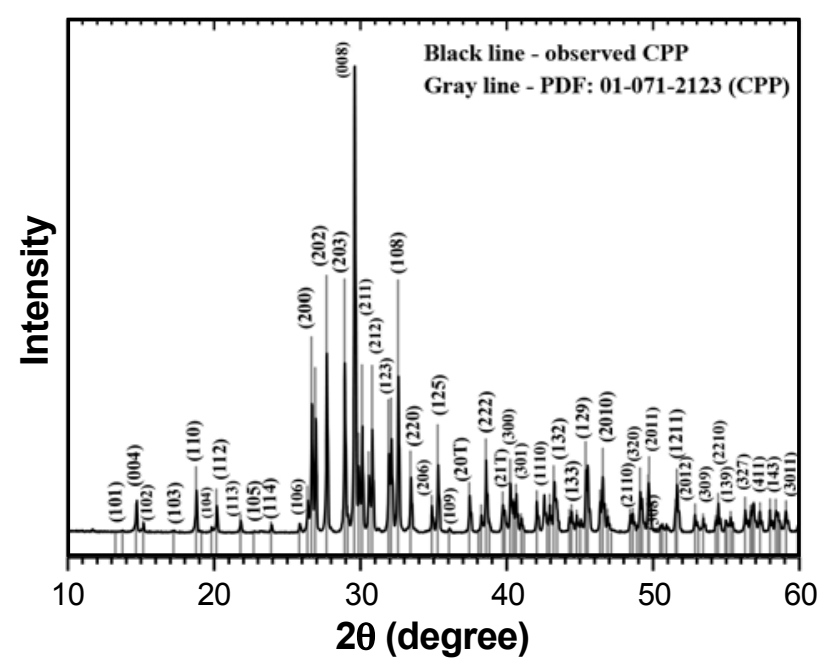

Figure 1: X-ray diffraction pattern of $\beta$-CPP powder. [Figura 1: Difratograma de raios $X$ do pó de $\beta$-CPP.]

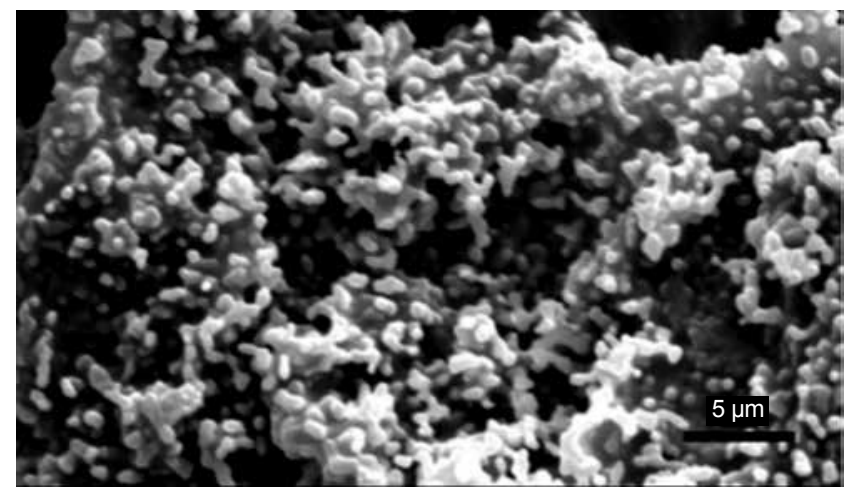

Figure 2: SEM micrograph of $\beta$-CPP powder.

[Figura 2: Micrografia obtida por microscopia eletrônica de varredura do pó de $\beta$-CPP.]

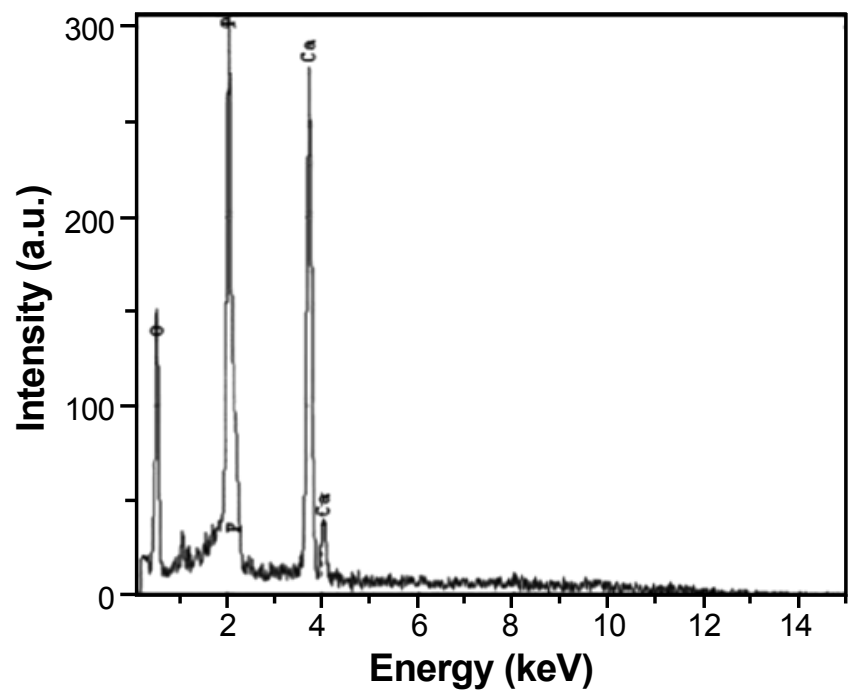

Figure 3: EDS spectrum of $\beta$-CPP powder. [Figura 3: Espectro de EDS do pó de $\beta$-CPP.] 


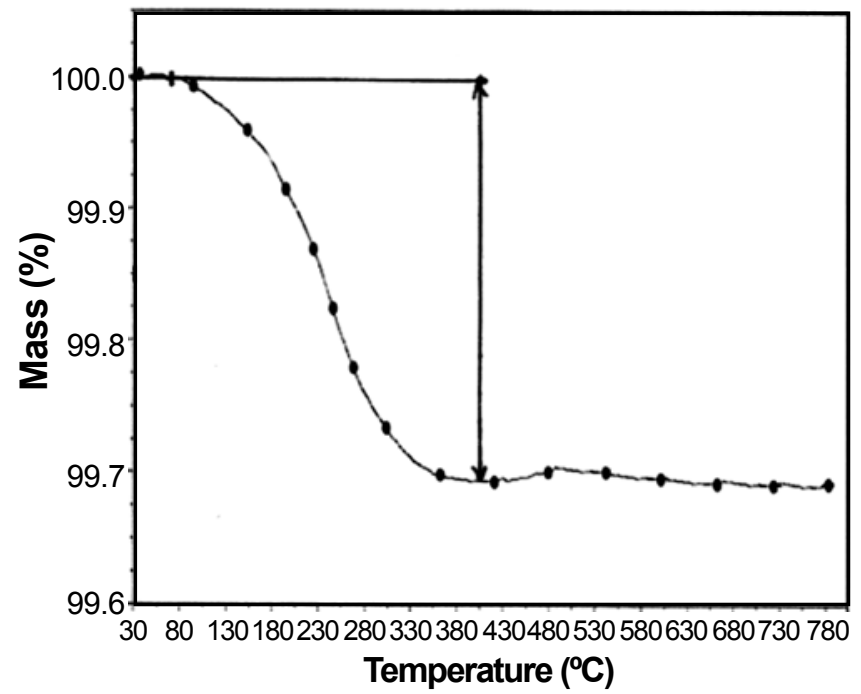

Figure 4: Thermogravimetric analysis of $\beta$-CPP powder. [Figura 4: Análise termogravimétrica do pó de $\beta$-CPP.]

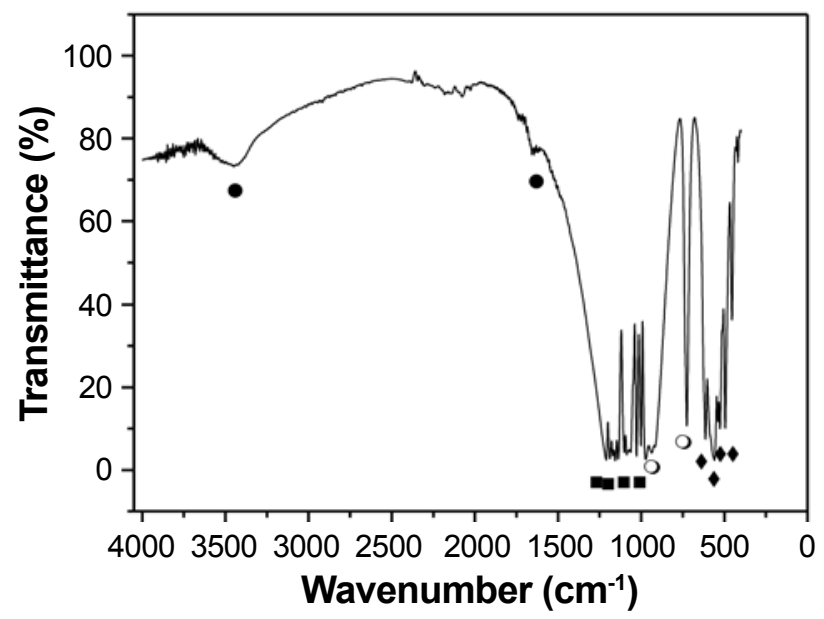

Figure 5: FTIR spectrum of $\beta$-CPP powder: $\bullet \mathrm{H}_{2} \mathrm{O}$; $\mathbf{\square} \mathrm{PO}_{3}{ }^{2-}$; $\mathrm{O} \mathrm{CO}_{3}{ }^{2-}$; and $\diamond \mathrm{PO}_{4}{ }^{2-}$.

[Figura 5: Espectro de FTIR do pó de $\beta$-CPP.]

Fig. 4 shows the results of thermogravimetric analysis of $\beta$-CPP. As may be observed, the $\beta$-CPP powder exhibited high thermal stability during the heating period. In fact, it was found only a small total weight loss of $0.3 \%$, which is associated to the removal of physically adsorbed water on the $\beta$-CPP powder particles.

Fig. 5 shows the FTIR spectrum of the synthesized $\beta$-CPP powder. The frequency bands related to vibrational groups of $\beta$-CPP are interpreted as follow $[5,9,13,15]$. The spectrum displays a broad band centered at $3410 \mathrm{~cm}^{-1}$ and another weak band at $1640 \mathrm{~cm}^{-1}$ that corresponds to binding mode of adsorbed $\mathrm{H}_{2} \mathrm{O}$. Several bands observed at 960 , 1010,1035 , and $1120 \mathrm{~cm}^{-1}$ were attributed to the symmetric $\mathrm{P}-\mathrm{O}$ stretching of $\mathrm{PO}_{3}{ }^{2-}$ groups. The bands around 720 and $885 \mathrm{~cm}^{-1}$ represent the asymmetric $\mathrm{C}-\mathrm{O}$ stretching of $\mathrm{CO}_{3}{ }^{2-}$ group. The bands observed around 450, 480, 581, and 620 $\mathrm{cm}^{-1}$ appeared due to the asymmetric O-P-O stretching of $\mathrm{PO}_{4}^{2-}$ group. These results are in agreement with those obtained from XRD (Fig. 1), SEM (Fig. 2), EDS (Fig. 3), and TGA (Fig. 4), which demonstrated that it is possible to convert the avian eggshell waste into pure $\beta$-CPP powder.

\section{CONCLUSIONS}

This work has demonstrated the first example of pure $\beta$-CPP powder with nanometric crystallites prepared by using avian eggshell waste as the calcium precursor source. XRD and SEM revealed the nanostructured nature of the synthesized $\beta$-CPP powder with average crystallite size of $62.3 \mathrm{~nm}$. SEM analysis also revealed that the particles presented spherical morphology. FTIR analysis confirmed the presence of all the characteristics bands of $\beta$-CPP. Thus, the avian eggshell waste seems to be very promising for synthesizing pure $\beta$-CPP powder with nanometric crystallites as candidate for application as bone graft material.

\section{ACKNOWLEDGEMENTS}

The authors would like to thank CNPq and FAPERJ for the financial support, and also to the Teresa Eglisio by the support in TG analysis.

\section{REFERENCES}

[1] J.B. Park, R.S. Lakes, Biomaterials: an introduction, Plenum Press, New York (1992).

[2] L.L. Hench, J. Am. Ceram. Soc. 81, 7 (1998) 1705-1728.

[3] T.V.Safronova, V.I. Putlayev, K.A. Bessonov, V.K. Ivanov, Proces. Appl. Ceram. 7, 1 (2013) 9-14.

[4] J.H. Lee, D.H. Lee, H.S. Ryu, B.S. Chang, K.S. Hong, C.K. Lee, Key Eng. Mater. 240-242 (2003) 399-402.

[5] S.R. Vasant, M.J. Joshi, Mod. Phys. Lett. B 25, 1 (2011) 53-62.

[6] P.J. Groves, R.M. Wilson, P.A. Dieppe, R.P. Shellis, J. Mater. Sci.: Mater. Med. 18, 7 (2007) 1355-1360.

[7] J.J. Bian, D.W. Kim, K.S. Hong, J. Eur. Ceram. Soc. 23 (2003) 2589-2592.

[8] S.J. Lee, S.H. Oh, Mater. Lett. 57 (2003) 4570-4574.

[9] S.J. Lee, Y.S. Yoon, M.H. Lee, N.S. Oh, Mater. Lett. 61 (2007) 1279-1282.

[10] K.P. Sanoch, M.C. Chu, A. Balakrishnan, T.N. Kim, S.J. Cho, Mater. Lett. 63 (2009) 2100-2102.

[11] G.S. Kumar, A. Thamizhavel, E.K. Girija, Mater. Lett. 76 (2012) 198-200.

[12] A.R. Ibrahim, W. Wei, D. Zhang, H. Wang, J. Li, Mater. Lett. 110 (2013) 195-197.

[13] P. Kamalanathan, S. Ramesh, L.T. Bang, A. Niakan, C.Y. Tan, J. Purbolaksono, H. Chandran, W.D. Teng, Ceram. Int. 40 (2014) 16349-16359.

[14] L.C. Gomes, B.C. DiLello, J.B. Campos, M. Sampaio, Cerâmica 58 (2012) 448-452.

[15] L. Sun, L.C. Chow, S.A. Frukhtbeyn, J.E. Bonevich, J. Res. Natl. Inst. Stand. Technol. 115 (2010) 243-255.

(Rec. 18/09/2015, Rev. 27/11/2015, 14/12/2015, 07/01/2016, Ac. 19/03/2016) 